\title{
Carbohydrate Profiling of a Few Rice Products of Assam having Ethno-Economic Importance
}

\author{
Suchandra Bhattacharjee ${ }^{1}$, Priyanka Das ${ }^{1}$, Khanin Pathak ${ }^{1}$, Tankeshawar Nath ${ }^{2}$, \\ Nayanjyoti $\mathrm{Ojha}^{3}$ and Smrita Barua ${ }^{4}$
}

${ }^{1}$ Department of Biochemistry and Agricultural Chemistry, ${ }^{2}$ Department of Agricultural Biotechnology, ${ }^{3}$ Department of Agronomy, ${ }^{4}$ Department of Agricultural statistics, Assam Agricultural University, Jorhat-785013, India

*Corresponding author

\section{A B S T R A C T}

\begin{tabular}{|c|}
\hline Keywords \\
\hline $\begin{array}{l}\text { hurum, komal } \\
\text { chaul, bhoja bora, } \\
\text { flaked rice, korai, } \\
\text { sandahguri, } \\
\text { traditional rice } \\
\text { products }\end{array}$ \\
\hline Article Info \\
\hline $\begin{array}{l}\text { Accepted: } \\
28 \text { November } 2019 \\
\text { Available Online: } \\
10 \text { December } 2019\end{array}$ \\
\hline
\end{tabular}

\section{Introduction}

Rice (Oryza sativa L.) is considered as the major source of nutrients in many parts of the world It provides carbohydrates, proteins,
Rice is known as the 'grain of life'. It is the staple food for more than half of the world's population. Due to processing, alteration of nutritional quality takes place either by changes in nutrients or by an improvement in digestibility of nutrients. Hurum, komal chaul, bhoja bora, puffed rice, popped rice, flaked rice, korai, sandahguri are the rice products obtained from specialty rice varieties of Assam. A unique characteristic of these rice products is that the products can be used instantly. Considering paucity of information on changes involved during processing of such products made from speciality rice of Assam, the present investigation was conducted. The present study revealed that, on dry weight basis, the total carbohydrate, starch, amylose, resistant starch and total soluble sugar content ranged between $88.53 \%-92.17 \%, 42.39 \%-76.34 \%, 6.60 \%-14.29 \%$, $3.96 \%-6.15 \%$ and $6.22 \%-10.85 \%$, respectively. The present study revealed higher amount of resistant starch (5\% to less than $15 \%$, classified as high group) in products like hurum, komal chaul, bhoja bora, flaked rice, korai and sandahguri than their respective raw forms. Detection of an appreciable amount of resistant starch imparts nutritional importance to these traditional rice products, already having ethno economic importance. 
Parboiling is a process developed for improving rice quality and it consists of soaking, steaming and drying of the rough rice. The major reasons for parboiling include higher milling yields, higher nutritional value and resistance to spoilage by insects and mold. It hardens the kernel in order to maximize head rice yield in milling. Nutritional and health benefits of parboiled brown rice are more compared to the raw brown rice and so the awareness and importance of parboiling are increasing day by day among consumers and manufacturers ${ }^{4}$.

In Assam too, a variety of traditional ready to eat products from rice are processed, in which parboiling is involved. Due to processing, alteration of nutritional quality takes place either by changes in nutrients or by an improvement in digestibility of nutrients. Hurum, komal chaul, bhoja bora, puffed rice, popped rice, flaked rice, korai, sandahguri are the rice products obtained from specialty rice varieties of Assam, particularly bora (low amylose containing) and chakua (intermediate amylose containing). A unique characteristic of these rice products is that the products can be used instantly.

However, no reports can be traced on biochemical changes taking place during processing of speciality rice products of Assam. Considering limited information on the carbohydrate profiling of the traditional rice products of Assam having ethno economic importance together with the changes involved during processing, the present work was carried out.

\section{Materials and Methods}

\section{The rice and the products}

The specialty rice products Bhoja bora, Korai, Komal chaul and Sandahguri along with the intermittent form 1 (for bhoja bora) and the respective raw/ brown forms of rice (Michi bora and Ranga chakua, respectively) were collected from Jamuguri village near the campus of Assam Agricultural University, Jorhat, Assam. The specialty rice products Hurum and flaked rice along with the intermittent form 2 (for hurum) and the respective raw/ brown form of rice (Bakul bora) were collected from Pukhuria village near Mariani. All these rice products of Assam, having ethno- economic importance prepared through traditional method are described below.

\section{Bhoja bora}

Michi bora paddy (about $400 \mathrm{gm}$ ) was soaked in normal water for 24 hours at room temperature and after that, water was drained out. At this stage the sample was collected to be analyzed as intermittent product 1(after dehusking). The paddy was then fried in an iron vessel over wood fire with constant stirring for about 20 mins (The grain temperature recorded to be approximately $\left.105^{\circ} \mathrm{C}\right)$. Cooling was done by spreading these grains over mud floor for few mins before milling in a dheki (foot operated wooden traditional milling device). Lastly, sieving was done to get bhoja bora chaul

\section{Korai}

Korai was prepared by frying the dehusked whole michi bora rice on hot pan with constant stirring for about 3 mins (approximately at $100^{\circ} \mathrm{C}$ ). Then grinding was done using domestic mixer grinder. Then sieving was done using $50 \mu$ sieve to get the final product korai.

\section{Hurum}

Bakul bora paddy (about 200 gm) was soaked in normal water for 24 hours at room temperature and then treated with boiling 
water for about 10 mins. After draining the water, the paddy was fried in an iron vessel over wood fire with constant stirring for about 15 mins (approximately at $103^{0} \mathrm{C}$ grain temperature).

It was followed by cooling, which was done by spreading these grains over mud floor for few mins. After completion of cooling, the sample was collected for analysis as intermittent product 2 (after dehusking). The previous step was followed by milling using a dheki. After sieving, it was again fried in sand for about $3 \mathrm{~min}$ (approximately at temperature $45^{\circ} \mathrm{C}$ ). Lastly, sieving was done to get the product hurum.

\section{Flaked rice}

Bakul bora paddy (about 200 gm) was soaked in normal water for 24 hours at room temperature and then room shading was done for few mins.

Then the paddy was roasted in an iron vessel over wood fire with constant stirring for about 3 mins (approximately at $90^{\circ} \mathrm{C}$ ). Cooling was done by spreading these grains over mud floor for few min before milling in a dheki. Lastly, sieving was done to remove the husk and the flaked rice was collected.

\section{Komal chaul}

Ronga chakua paddy (about 400 gm) was soaked in normal water for 24 hours at room temperature and after draining the water, it was treated with warm (approximately at $78^{\circ} \mathrm{C}$ ) water for about $25 \mathrm{~min}$ over wood fire till the husk started splitting.

The water is again drained and the grains were dried under the Sun on the same day. Dried grains were milled in a dheki. Lastly, sieving was done to remove the husk and the product komal chaul was collected.

\section{Sandahguri}

Sandahguri was prepared by frying the specialty rice product komal chaul on hot pan with constant stirring for about 6 mins (approximately at $101^{\circ} \mathrm{C}$ ). Then grinding was done in domestic mixer grinder. Then sieving was done using $50 \mu$ sieves (optional) to get the final product sandahguri.

\section{Biochemical Methods}

The total carbohydrate content on dry weight basis was calculated by subtracting the sum of the values $(\%)$ of crude protein, ash, crude fat and crude fibre content (all on dry weight basis) from $100{ }^{5}$ (The data of crude protein, ash, crude fat and crude fibre content were taken from elsewhere) ${ }^{6}$. The total soluble sugar estimated by the Anthrone Method ${ }^{7}$. The starch content in the sample was estimated by the method described by Chopra and Konwar ${ }^{8}$. The amylose content was estimated by the method given by Sowbhagya, and Bhattacharya ${ }^{9}$. The resistant starch of the specialty rice and their products was estimated by the method given by Goni et al., $1996^{10}$. The data obtained from various biochemical analyses were subjected to statistical analysis using completely randomized design.

\section{Results and Discussion}

The total carbohydrate content of specialty rice and their products is presented in Table1 and Fig. 1. The total carbohydrate content of brown form of specialty rice was found to be $91.12 \%$ to $92.17 \%$. The lowest was observed in Ronga chakua and the highest in Bakul bora. The total carbohydrate content was found to be higher than the values $(69.30 \%$ $85.90 \%$ ) reported for brown form of chakua rice varieties of Assam ${ }^{11}$. The values observed in the present study were also found to be slightly higher than the values $(80.62 \%$ $90.80 \%$ ) reported for few indigenous red 
grained cultivars of Assam ${ }^{12}$. The significant variation in the total carbohydrate content of raw form of specialty rice might be mainly due to the genetic differences among the rice varieties used for processing.

The total carbohydrate content of different products and their intermittent forms varied from $88.53 \%$ to $91.63 \%$, the lowest was observed in sandah guri and the highest in the intermittent form 2. Similar observations (Komal chaul, Bhoja bora chaul, Flaked rice, Hurum, Sandahguri, and Korai to be $90.28 \%$, $88.67 \%, 89.48 \%, 89.33 \%, 90.07 \%$, and $89.30 \%$, respectively) were reported for some traditional rice products of Assam ${ }^{13}$. The total carbohydrate content of roasted rice and flaked rice were reported to be $70.69 \pm 0.69 \%$ and $77.75 \% \pm 0.60 \%$, respectively in comparison to $77.57 \pm 0.22 \%$ in raw form ${ }^{14}$. In the present study, higher total carbohydrate content of flaked rice $(90.47 \%)$ was observed. It was reported that after parboiling the total carbohydrate content decreased in the rice product than their respective raw form due to the presence of higher sum total of other nutrients like crude protein, crude fibre and ash as compared to corresponding raw form ${ }^{15}$. In the present study too, the total carbohydrates content of komal chaul and Ronga chakua were observed to be $88.97 \%$ and $91.12 \%$, respectively suggesting a decrease during processing. The similar trend (decrease in the content than their respective raw form) was observed for some of the products and intermediate forms, which might be due to loss during soaking, as it caused the leaching of rice constituents in the soaking water. It was reported that the starch and amylose content of rice decreased due to leaching of starch granules; thereby reducing rice quality ${ }^{2}$. In the present study too, the decrease in total carbohydrate was associated with decrease in starch and amylose content, which are discussed later on. In the present study, in comparison to the decrease in starch content, the decrease in total carbohydrate content was not much, which might be due to conversion of starch to sugars during the step involved in frying/ heating. Earlier, it was reported that severe heating for prolonged time might lead to rapture of glycosidic linkages ${ }^{16}$. However, the decrease during the formation of korai and sandahguri from michi bora and komal chaul respectively, might be due to sieving before collecting the final product, in which carbohydrate rich hard portion might be eliminated.

The total soluble sugar content of specialty rice and their products is presented in Table 1 and Fig.2. The total soluble sugar content of raw form of specialty rice was found to be $8.08 \%$ to $10.85 \%$, the lowest was observed in Michi bora and the highest in Bakul bora. The value was found to be higher than the values $(3.24 \mathrm{mg} / \mathrm{g}-7.03 \mathrm{mg} / \mathrm{g})$ reported for raw paddy, which might be due to differences in varieties and degrees of polishing ${ }^{17}$. The significant variation in the total soluble sugar content of different raw forms of specialty rice might be due to the varietal differences.

The total soluble sugar content of different products and their intermittent forms varied from $6.22 \%-10.15 \%$, the lowest was observed in komal chaul and the highest in korai. Lower value $(3.52 \mathrm{mg} / \mathrm{g}-7.54 \mathrm{mg} / \mathrm{g})$ of total soluble sugar was reported for popped paddy ${ }^{17}$.The significant variation in the total soluble sugar content of different products and their intermittent forms might be due to the differences in method of processing (soaking, heating, frying/ roasting, etc). The dorsal portion of the milled grain contained the greatest amount of soluble sugar, approximately ten fold the amount found in the central core of the grain ${ }^{18,19,20}$. The high sugar content in the outer caryopsis required that comparisons of sugar content between rice cultivars be made with grain milled to the same degree ${ }^{18}$. In the present study, the 
decrease in TSS was observed to be the highest in the formation of komal chaul (3.72\%) which might be due to soaking of the paddy in warm water. However, in korai and sandah, the observed increase in total soluble sugar after the heat treatment (frying/roasting) might be mainly due to hydrolysis of a portion of starch to simple sugars as the rupture of glycosidic linkages during processing (prolonged heating) was reported ${ }^{16}$. Hydrolysis of starch as a result of heat treatments was also reported ${ }^{21}$.

Table.1 Carbohydrate profiling (\%, dry weight basis) of specialty rice and their products

\begin{tabular}{|c|c|c|c|c|c|}
\hline Rice forms & $\begin{array}{l}\text { Total Carbo- } \\
\text { hydrate }\end{array}$ & $\begin{array}{l}\text { Total soluble } \\
\text { sugar }\end{array}$ & $\begin{array}{l}\text { Total } \\
\text { starch }\end{array}$ & Amylose & $\begin{array}{c}\text { Resistant } \\
\text { starch }\end{array}$ \\
\hline $\begin{array}{l}\text { Michi bora } \\
\text { (brown) }\end{array}$ & $91.71(81.15)$ & $8.08(7.09)$ & $\begin{array}{c}74.42 \\
(66.86)\end{array}$ & 8.09 (7.16) & $3.96(3.51)$ \\
\hline Korai & $89.40(83.42)$ & $10.15(9.47)$ & $\begin{array}{c}43.31 \\
(40.42)\end{array}$ & $6.60(6.15)$ & $4.21(3.92)$ \\
\hline $\begin{array}{l}\text { Intermittent form } \\
1\end{array}$ & $90.87(78.60)$ & $6.59(5.91)$ & $\begin{array}{c}53.74 \\
(48.17)\end{array}$ & $7.49(6.51)$ & $4.96(4.45)$ \\
\hline Bhoja bora & $90.01(84.02)$ & $6.30(5.78)$ & $\begin{array}{c}46.87 \\
(43.80)\end{array}$ & $7.05(6.58)$ & $5.69(5.32)$ \\
\hline $\begin{array}{c}\text { Bakul bora } \\
\text { (brown) }\end{array}$ & $92.17(81.33)$ & $10.85(9.59)$ & $\begin{array}{c}70.09 \\
(61.85)\end{array}$ & $7.60(6.71)$ & $4.73(4.18)$ \\
\hline $\begin{array}{c}\text { Intermittent form } \\
2\end{array}$ & $91.63(78.41)$ & $9.27(8.21)$ & $\begin{array}{c}48.33 \\
(42.81)\end{array}$ & $7.53(6.45)$ & $5.25(4.63)$ \\
\hline Hurum & $90.97(83.55)$ & $7.03(6.45)$ & $\begin{array}{c}47.72 \\
(43.55)\end{array}$ & $7.25(6.65)$ & $5.69(5.22)$ \\
\hline Flaked rice & $90.47(78.32)$ & $9.44(8.22)$ & $\begin{array}{c}42.39 \\
(36.98)\end{array}$ & $7.36(6.38)$ & $5.44(4.71)$ \\
\hline $\begin{array}{c}\text { Rongachakua } \\
\text { (brown) }\end{array}$ & $91.12(78.31)$ & $9.94(8.54)$ & $\begin{array}{c}76.34 \\
(65.61)\end{array}$ & $14.29(12.28)$ & $4.97(4.27)$ \\
\hline Komalchaul & 88.97(79.07) & $6.22(5.53)$ & $\begin{array}{c}49.24 \\
(43.76)\end{array}$ & $11.47(10.2)$ & $5.77(5.13)$ \\
\hline Sandahguri & $88.53(80.99)$ & $8.69(7.96)$ & $\begin{array}{c}54.35 \\
(49.72)\end{array}$ & $12.34(11.29)$ & $6.15(5.62)$ \\
\hline Mean & $90.53(80.65)$ & $8.41(7.52)$ & $\begin{array}{c}55.14 \\
(49.41)\end{array}$ & 8.825 (7.85) & $5.17(4.63)$ \\
\hline $\mathrm{CD}(0.05)$ & 0.372 & 0.658 & 6.288 & 0.857 & 0.452 \\
\hline SE(m) & 0.130 & 0.229 & 2.183 & 0.290 & 0.157 \\
\hline SE(d) & 0.183 & 0.323 & 3.087 & 0.411 & 0.222 \\
\hline
\end{tabular}

NB: The data in parenthesis represent the content on fresh weight basis 
Fig.1 Total Carbohydrate Content (\%, Dry Weight Basis) of Specialty Rice and their Products

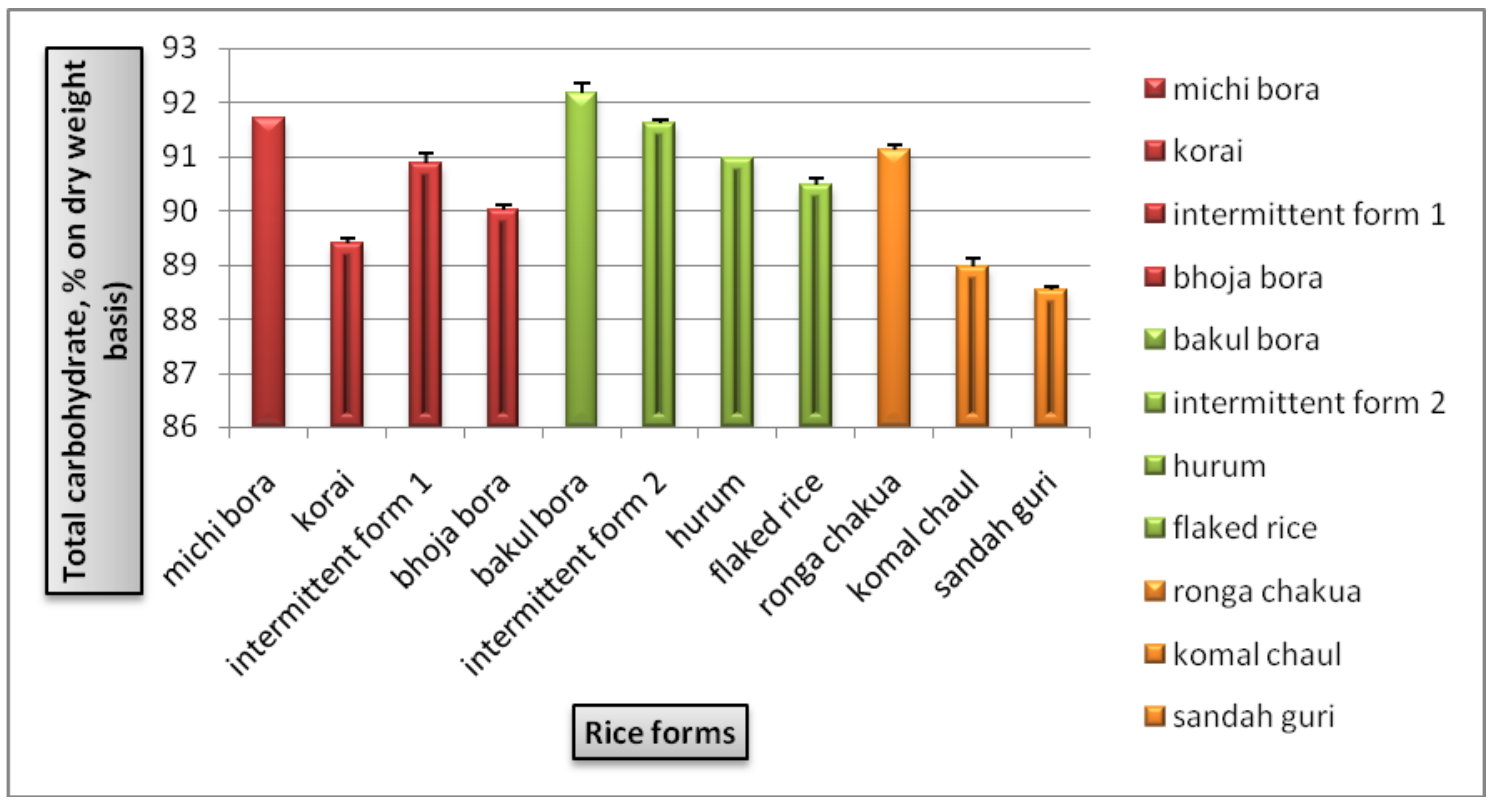

Fig.2 Total Soluble Sugar Content (\%, Dry Weight Basis) of Specialty Rice and their Products

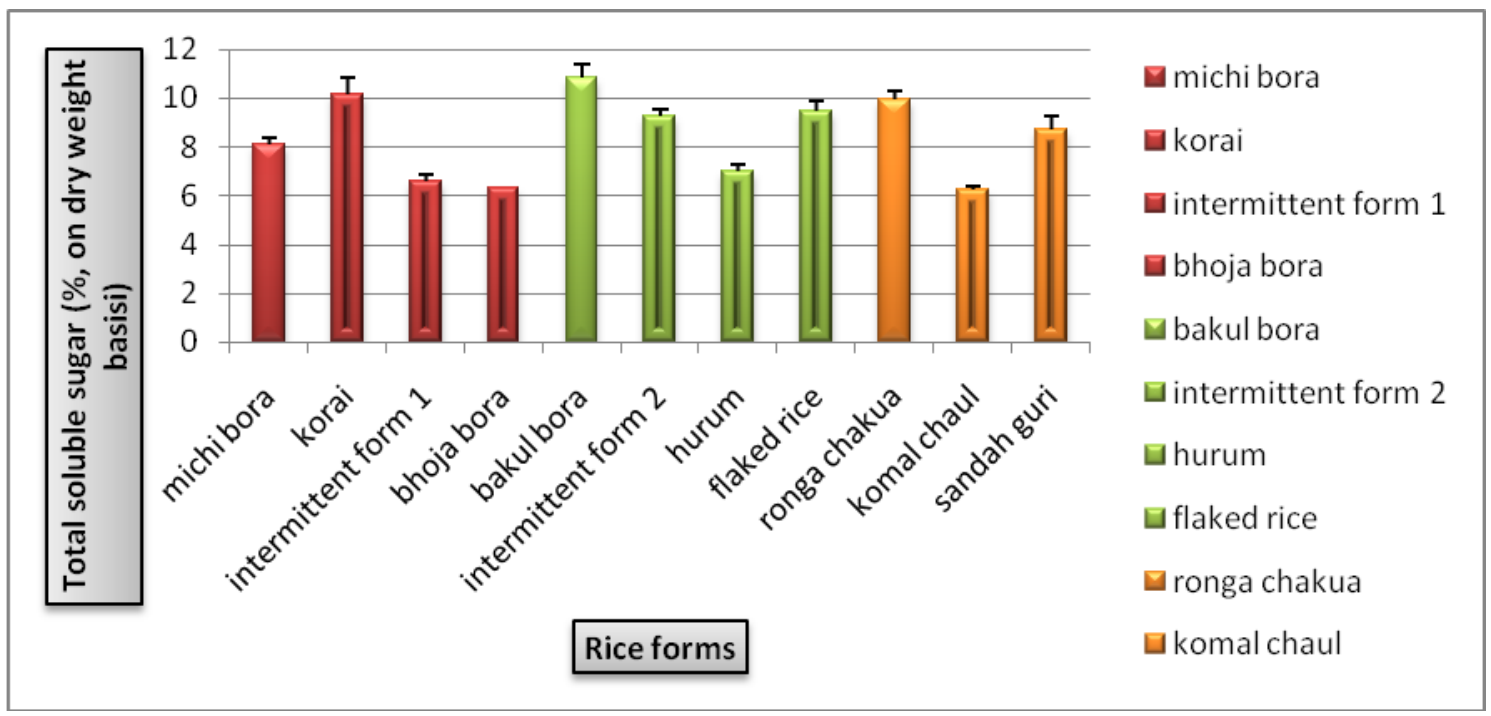


Fig.3 Starch Content (\%, Dry Weight Basis) of Specialty Rice and their Products

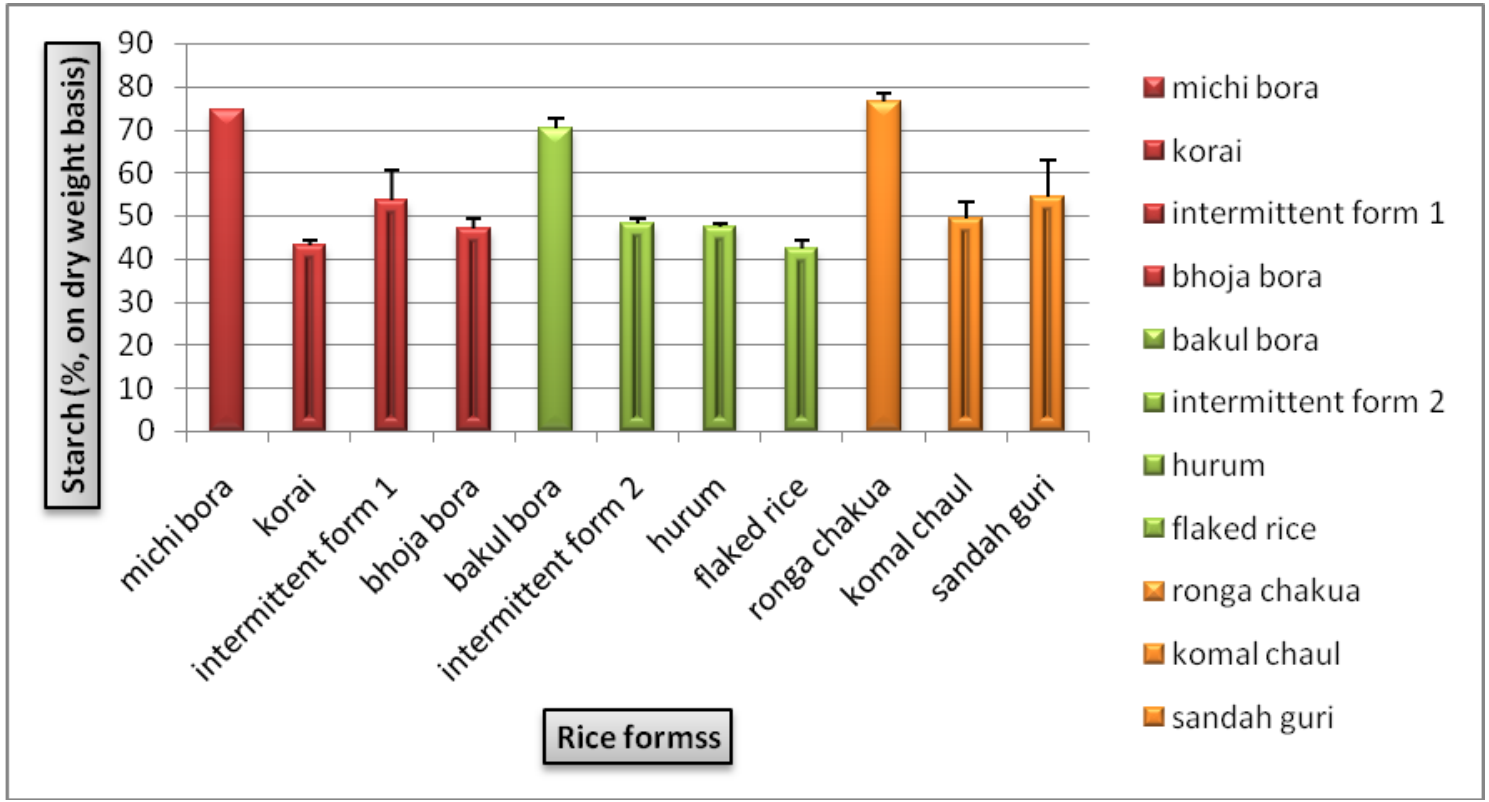

Fig.4 Amylose Content (\%, Dry Weight Basis) of Specialty Rice and their Products

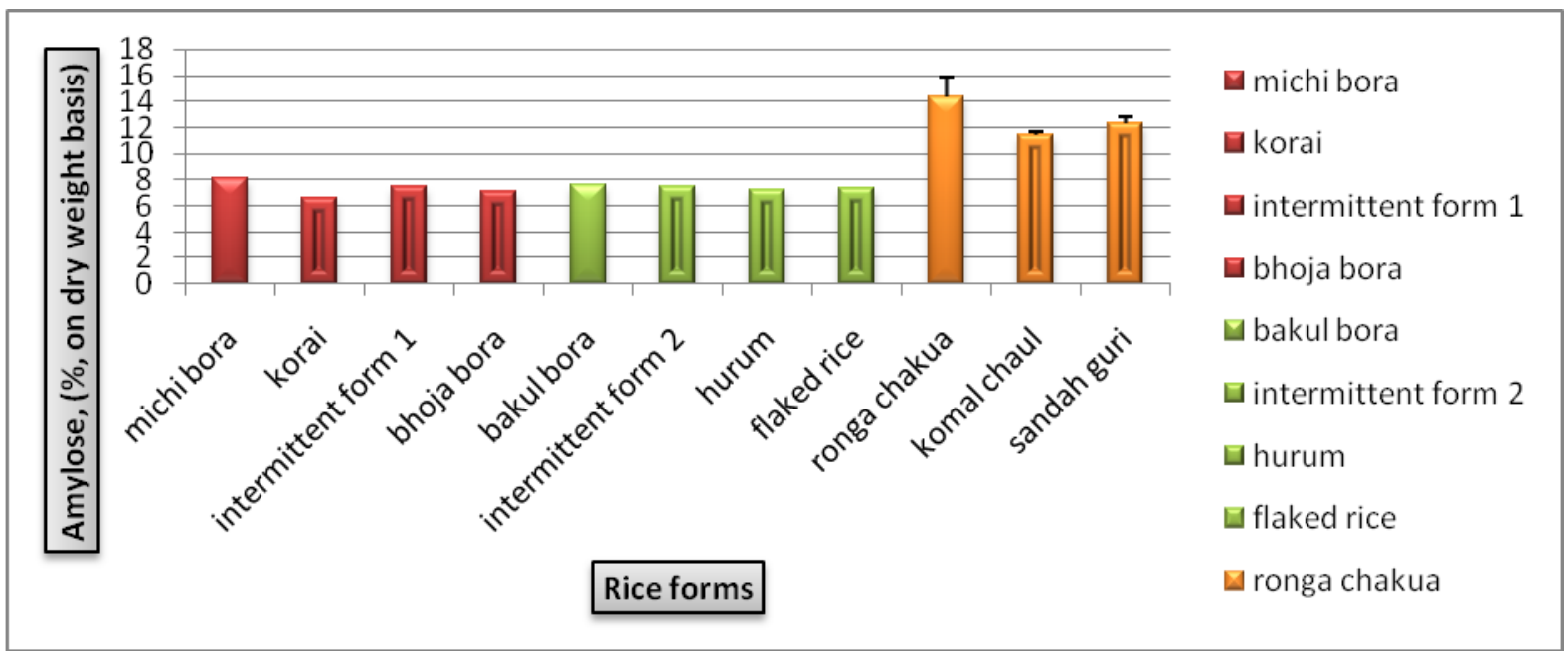


Fig.5 Resistant Starch Content (\%, Dry Weight Basis) of Specialty Rice and their Products

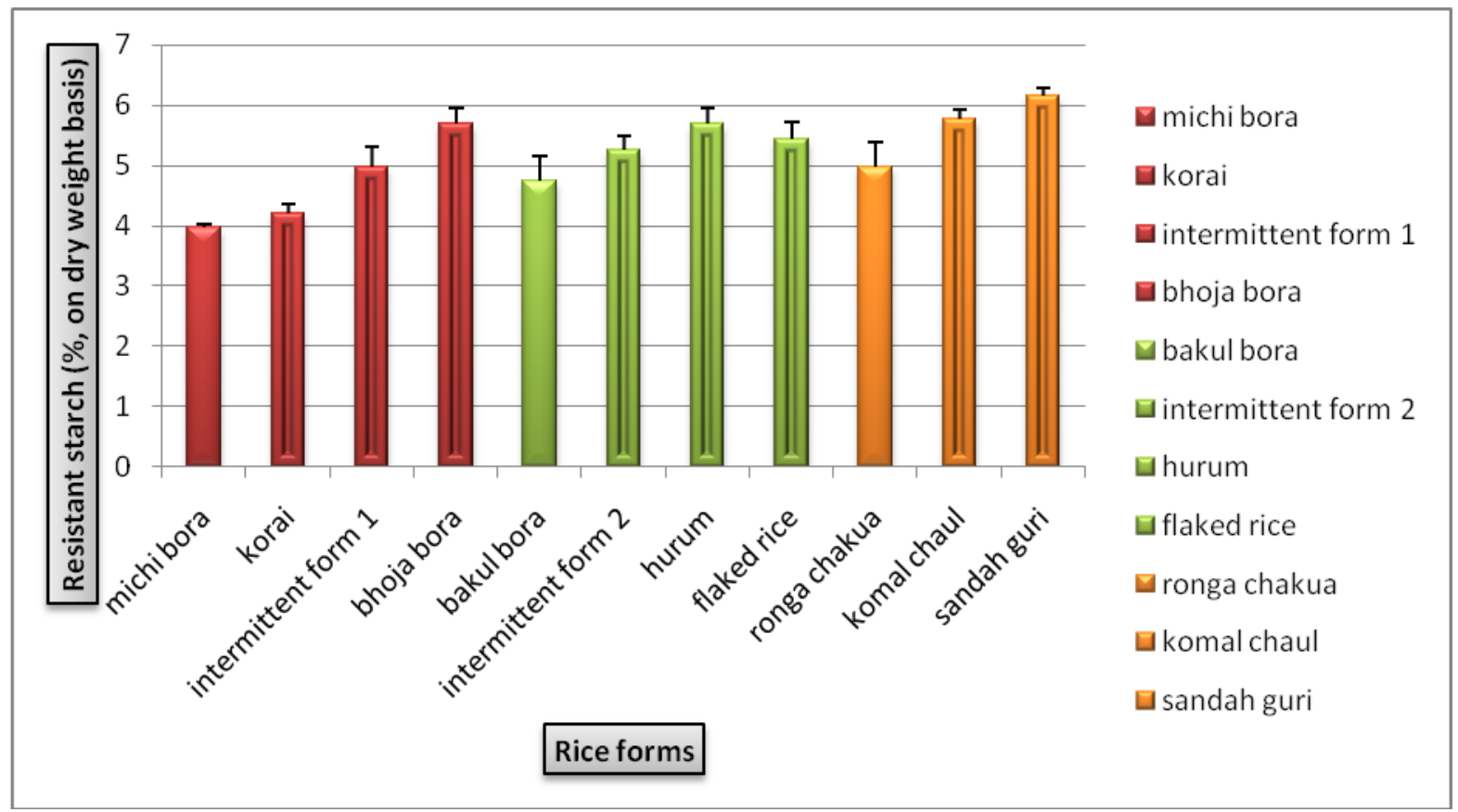

The starch content of specialty rice and their products is presented in Table 1 and Fig.3. In the present study, the starch content of raw form of specialty rice were found to be $70.09 \%-76.34 \%$, the lowest was observed in Bakul bora and the highest in Ronga chakua. The result of the starch for the present investigation was found to agree with those of the findings for some hill rice cultivars of Assam $^{22}(70.31 \%-78.19 \%)$, for brown rice $(73.24 \%)^{2}$ and for some glutinous rice cultivars of Assam ${ }^{23}$ (70.37\% - 82.83\%). The significant variation in the starch content of raw form of specialty rice might be mainly due to the genetic differences among the rice varieties used for processing.

The starch content of different products and their intermittent forms varied from $42.39 \%$ $54.35 \%$, the lowest was observed in flaked rice and the highest in sandah guri. Similar observations (Komal chaul, Bhoja chaul, Flaked rice, Hurum, Sandahguri, and Korai to be $43.33 \%, 48.16 \%, 44.78 \%, 40.59 \%$, $51.62 \%$, and $39.89 \%$, respectively) were reported for some traditional rice products of
Assam $^{13}$. In the present study, the starch content of flaked rice $(42.39 \%)$ was found to be lower than the values $(81.05 \%-81.41 \%)$ reported for flaked rice ${ }^{24}$. It was reported earlier that the starch content of roasted rice and flaked rice were $78.11 \pm 0.62 \%$ and $79.20 \pm 0.46 \%$, respectively ${ }^{14}$. During any type of processing step (soaking, heating, milling, etc), a portion of starch granules may sustain mechanical damage (including starch gelatinization), whose level varies with the severity of processing conditions employed ${ }^{25}$.

In the present study, the specialty rice products underwent a number of processing steps, resulting in a decrease of starch content. When the rice seeds were hydrated, the activities of hydrolytic enzymes like amylase, protease, phosphatase and $\beta$-glucosidase increased, simpler sugars and proteins were formed and released into the soaking unit ${ }^{26}$. It was reported that the starch and amylose content of rice decreased due to leaching of starch granules, thereby reducing rice quality ${ }^{2}$. The amylose content of specialty rice and their products is presented in Table 1 and Fig.4. 
The amylose content of brown form of specialty rice was found to be $7.60 \%$ to $14.29 \%$, the lowest was observed in Bakul bora and the highest in Ronga chakua. The result did not vary from the range reported for some bora varieties of $\operatorname{Assam}^{27}(1.1 \%$ $27.2 \%$ ), for some glutinous rice cultivars of $\operatorname{Assam}^{23}(0.10 \%-29.60 \%)$, for raw rice of some Indian cultivars ${ }^{17}(5.32 \%-26.58 \%)$, for some brown form of chakua rice varieties of Assam $^{11}(9.12 \%-14.84 \%)$ and for few indigenous red grained rice cultivars of Assam $^{12}$ (0.20\%- 20.98\%), respectively. The amylose content of the present investigation was found to be lower than the values (18.61\%-23.39\%) for some hill rice cultivars of Assam ${ }^{22}$.

The amylose content of different products and their intermittent forms varied from $6.60 \%$ $12.34 \%$, the lowest was observed in korai and the highest in sandah guri. Similar observation (3.99-23.94\%) was reported for popped paddy ${ }^{17}$. However, the present values were found to be lower than the values (Komal chaul, Bhoja chaul, Flaked rice, Hurum, Sandahguri, and Korai to be $16.80 \%, 19.53 \%$, $19.80 \%, 16.86 \%, 17.30 \%$, and $19.62 \%$, respectively) reported earlier for some traditional rice products of Assam ${ }^{13}$ and they suggested that the higher amylose content observed in that study for the rice products made from bora varieties might be due to the breakage of glycosidic linkage present in amylopectin. The present finding on the amylose content of flaked rice $(7.36 \%)$ was also found to be lower than the values $(19.56 \%$ - $19.91 \%)$ reported for thick and extra thick flaked rice ${ }^{24}$, which might be due to processing of flaked rice in the present study from low amylose containing bora variety. In the present study, the variation in the amylose content of different brown forms of specialty rice might be due to the differences in the genetical make up of the varieties. The significant variation in the amylose content of different specialty products and their intermittent products made from the same variety might be due to the solubility of starch in warm water and leaching of the amylose molecules into the surrounding water during soaking. Decrease in amylose content in the specialty rice product and intermittent forms than their respective raw rice might be also due to the partial gelatinization and retrograded starch formation at high temperature (during roasting) and resulting in conversion of amylose into resistant $\operatorname{starch}^{14}$.

The resistant starch (RS) content of specialty rice and their products is presented in Table 1 and Fig.5. In the present study, the resistant starch content of brown form of specialty rice were found to be $3.96 \%$ to $4.97 \%$, the lowest was observed in Michi bora and the highest in Ronga chakua. Similar observation (0.30 \pm 0.02 to $4.65 \pm 0.19 \%$ ) was reported for thirty eight selected rice varieties of Sri Lanka ${ }^{28}$. During the present investigation, the RS content of raw rice was found to be lower than the values $(6.6 \%)$ reported for rice ${ }^{10}$. The significant variation in the RS content of different brown form of specialty rice might be due to the varietal differences present in the raw rice in amylose content.

The RS content of different products and their intermittent forms varied from $4.21 \%-6.15 \%$, the lowest was observed in korai and the highest in sandah guri. Earlier, the RS of komal chaul, bhoja chaul, flaked rice, hurum, sandahguri, and korai were reported to be $4.91 \%, 5.26 \%, 3.64 \%, 5.12 \%, 5.42 \%$, and $4.11 \%$, respectively ${ }^{13}$. However, lower values $(0.98 \pm 0.04 \%$ and $0.92 \pm 0.03 \%$, respectively) for the RS content of roasted rice and flaked rice were reported ${ }^{14}$. In the present study, the higher resistant starch content of flaked rice $(5.44 \%)$ was observed. RS content were observed to increase in the specialty rice products and intermittent products from their respective raw forms which might be due to the different methods of processing (soaking, 
heating, period of cooling, etc). Thus, it might lead to formation of retrograded starch (RS3), as for all the products presently studied, heating followed by cooling was practised. The present study reveals that the analyzed raw rice forms of all the three varieties and the product korai and initermittent form 1 contained intermediate $(2.5-5 \%$, dry basis) amount of RS, whereas, the same in initermittent form 2, sandah guri, bhaja bora and hurum, flaked rice and komal chaul contained RS in high group (5\% to less than $15 \%)$. Detection of an appreciable amount of RS imparts nutritional importance to these traditional rice products, already having ethno economic importance. Though, considering malnutrition, food with the highest starch digestibility and low resistant starch should be used, diabetic patients should consume cereals with high RS content eliciting a low postprandial glycemic response ${ }^{29}$.

\section{Acknowledgement}

The authors express gratitude to Assam Agricultural University, Jorhat-785013, India for financial assistance to carry out the study.

\section{References}

1. Kale, S. J.; Jha, S. K.; Jha, G.K.; Sinha, J.P. and Lal, S. B. (2015). Soaking induced changes in chemical composition, glycemic index and starch characteristics of basmati rice. Rice. Sci. 22(5): 227-236.

2. Dutta, H. and Mahanta, C.L. (2014). Traditional parboiled rice-based products revisited: Current status and future research challenges. Rice. Sci. 21(4): 187200.

3. Pinkrova, J.; Hubackova, B.; Kadlec P.; Prihoda, J. and Bubnik, Z. (2003): Changes of starch during microwave treatment of rice. Czech. J. Food Sci. 21: 176- 184.

4. Sareepuang, K.; Siriamornpum, S.; Wiset, L. and Messo, N. (2008). Effect of
Soaking Temperature on Physical, Chemical and Cooking Properties of Parboiled Fragrant Rice. World. J. Agril. Sci.4 (4): 409-415.

5. Gopalan, G.; Ramasastri, B.V. and Balasubramanian, S.C. (2000). Nutritive value of Indian Foods. Indian. Council. Med Res. Hyderabad.

6. Bhattacharjee, S. (2019). Carbohydrate and micronutrient profiling of a few indigenous rice varieties of Assam and their products. M.Sc (Agri) Thesis, Assam Agricultural University, Jorhat.

7. Yem, E. M. and Willis, A. J. (1954). The estimation of carbohydrates in plant extract by anthrone. Biochem. J. 57(3):508-514.

8. Chopra, S. L. and Konwar, J. S. (1976). In: Analytical Agricultural Chemistry. Kalyani Publ., Ludhiana.

9. Sowbhagya, C. M. and Bhattacharya, K. R. (1979). Simplified determination of amylose in milled rice. Starch. 31(5): 159- 163.

10. Goni, I.; Garcia-Diz, L.; Manas, E. and Saura- Calixto, F. (1996). Analysis of resistant starch: a method for foods and food products. Food. chem. 56(4): 445449.

11. Das,P.; Singha, A.D.; Goswami, K. and Sarmah, K. (2018). Detection of Nutritionally Significant Indigenous Rice Varieties from Assam, India. Bull. Env. Pharmacol. Life Sci. 7(4): 59-64.

12. Mudoi, T. and Das, P. (2018). Nutritional composition of traditional colored rice cultivars of Assam, India. Bull. Env. Pharmacol. Life Sci. 7(7): 10- 14.

13. Banik, R.; Das, P.; Deka, N. and Sarmah, T.C. (2018). Ready to use ethnic rice products of Assam, India: Potential source of resistant Starch. Bull. Env. Pharmacol. Life Sci. 7(4): 55-58.

14. Kumar,S. and Prasad, K. (2018). Changes in the characteristics of indica rice on the process of flaking. Int. J. Chem. Studies. 
6(2): 2310-2317.

15. Kashyap, A. and Mahanta, C. L. (2016). Physical properties and nutritive value of a popular Assamese breakfast cereal. Int. J. Home Sci. 2(2): 227-231.

16. Svihus, B.; Uhlen, A. K. and Harstad, O. M. (2005). Effect of starch granule structure, associated components and processing on nutritive value of cereal starch: A review. Animal. Feed. Sci. Technol. 122: 303-320.

17. Bagchi, T.B.; Sanghamitra, P.; Berliner, J.K.; Sarkar, A.; Kumar, A.; Ray, S. and Sharma, S. G. (2016). Assessment of physicochemical, functional and nutritional propertiesof raw and traditional popped rice. Indian. J. Trad. Knowledge. 15(4): 659-668.

18. Smyth, D. A. and Prescott, H. E. (1989). Sugar content and activity of sucrose metabolism enzymes in milled rice grain. Plant. Physiol. 89(3): 893-896.

19. Singh, R. and Juliano, B. O. (1977). Free sugars in relation to starch accumulation in developing rice grain. Plant Physiol. 59: 417- 421.

20. Smyth, D, A.; Repetto, B. M. and Seidel, N. E. (1986). Cultivar differences in soluble sugar content of mature rice grain. Physio. Plant. 68: 367-374.

21. Rehman, Z. and Shah, W. H. (2005). Thermal heat processing effects on antinutrients, protein and starch digestibility of food legumes. Food. Chem. 91: 327- 331

22. Pathak, K. (2008). Starch and protein profile of some hill rice (Oryza sativa L.) cultivars of Assam.M.Sc (Agri) Thesis, Assam Agricultural University, Jorhat.

23. Pathak, K. (2015). Bio prospecting of glutinous rice of Assam. PhD (Agri) Thesis, Assam Agricultural University, Jorhat.

24. Kumar, S.; Haq, R. U. and Prasad, K. (2016). Studies on physico-chemical, functional, pasting and morphological characteristics of developed extra thin flaked rice. J. Saudi Society Agric. Sci. 17(3): 259-267.

25. Mahadevamma, S. and Taranathan, R.N. (2007). Processed rice starch characteristics and morphology. European Food Res. Technol. 225(3-4): 603-612.

26. Xavier, I. J. and Anthoni, Raj. S.(1995). Enzyme changes in rough rice during parboiling J. Food. Biochem. 19(5): 381389.

27. Dutta, H. and Mahanta, C. L. (2012). Effect on hydrothermal treatment varying in time and pressure on the properties of parboiled rices with different amylose content. Food. Res.Int. 49(2): 655-663.

28. Abeysekera, W.K.S.M.; Arachchige, S.P.G.; James, S.; Sotheeswaran, S.; Thavarajah, D. and Thavarajah, P. (2018). Resistant Starch Content of Thirt Eight Selected Rice (Oryza sativa L.) varieties of Sri Lanka. J. Agric. Crops. 4(9):93-98.

29. Vaidya, R. H. and Sheth, M. K. (2011). Processing and storage of Indian cereal and cereal products alters its resistant starch content. J. Food. Sci. Technol. 48(5): 622-627.

\section{How to cite this article:}

Suchandra Bhattacharjee, Priyanka Das, Khanin Pathak, Tankeshawar Nath, Nayanjyoti Ojha and Smrita Barua. 2019. Carbohydrate Profiling of a Few Rice Products of Assam having Ethno- Economic Importance. Int.J.Curr.Microbiol.App.Sci. 8(12): 2902-2912. doi: https://doi.org/10.20546/ijcmas.2019.812.337 